\title{
Estrogenic Activity of Mahoni Seed Ethanolic Extract [Swietenia mahogany (L.) Jacq] on Uterus Weight, Bone Density and Mamae Gland Proliferation on Ovariectomized Rats
}

\author{
Poppy Anjelisa Zaitun Hasibuan ${ }^{1 *}$, Rosa Gloria Sitanggang ${ }^{2}$, Robbani Syahfitri Angkat ${ }^{2}$ \\ ${ }^{1}$ Department of Pharmacology Pharmacy, Faculty of Pharmacy, Universitas Sumatera Utara, Medan, Indonesia \\ ${ }^{2}$ Faculty of Pharmacy, Universitas Sumatera Utara, Medan, Indonesia
}

\begin{abstract}
Menopause is a hypoestrogenic condition due to decreased function of the ovary. During menopause there is no reserved ovum in the ovary, as a result the synthesis of estrogen by the follicles does not take place. Deficiency of estrogen can lead to discomfort and decrease in the women quality of life. Therefore, supplements from natural resources to reduce menopausal symptoms will be needed. The objectives of the study were to determine the effect of mahogany seeds ethanolic extract (MSEE) on the development of uterus, bone density, and mammae gland proliferation on ovariectomized rats. Extract was made by maceration using $96 \%$ ethanol as the solvent, then the study of estrogenic effect was carried out on 30 female rats which were divided into 6 groups. Group 1 (normal control), group 2 (positive control) given estradiol dose of $0.18 \mathrm{mg} / \mathrm{kg}$ body weight (BW), group 3 (negative control) given Na-CMC 1\% and group 4, 5, 6 given MSEE orally for 14 consecutive days with doses of $50,100,200 \mathrm{mg} / \mathrm{kg}$ BW. Data were analysed using ANOVA then continued with Tukey HSD Post Hoc test to see the differences between the treatments. The results of the study showed that MSEE was able to increase the weight of the uterus, the length of estrus phase in the estrus cycle, bone density and the mammae gland proliferation of rats. The results concluded that MSEE has phytoestrogenic effect on ovariectomized rats.
\end{abstract}

Keywords: phytoestrogen, ovariectomy, uterusweight, bonedensity, mammaeproliferation

\section{INTRODUCTION}

At the end of the reproductive period, women experience menopause which is a hypoestrogenic condition due to decreased function of the ovary. At the time of menopause there is no reserve of ovum in the ovary, as a result the synthesis of the hormone estrogen by the follicles also does not take place. Estrogen deficiency can lead to discomfort and decrease in the quality of life of women causing hot flashes, insomnia, sexual dysfunction, vaginal dryness, cardovascular disease, and bone loss (Liu, et al., 2018; Murkies, et al., 1998; Sirotkin and Harrath, 2014).

Submitted: January 17, 2020

Revised: May 15, 2020

Accepted: May 17, 2020

*Corresponding author: poppyanjelisa@usu.ac.id 
Hormonal replacement therapy to prevent the chronic condition of menopause has been using for long-term, but it cause bleeding, dependency, and breast cancer (Chlebowski, et al., 2009; Keiler, et al., 2017). Therefore, this study was conducted to evaluate the estrogenic effect of mahogany seeds.

Mahogany seeds contain secondary metabolites, namely flavonoids, glycosides and saponins (Prasetiawan, et al., 2017). One of the constituents of secondary metabolites that have a role as phytoestrogens is flavonoids. Phytoestrogens are strikingly similar in chemical structure to the mammalian estrogen, estradiol, and bind to estrogen receptors alpha and beta (Sirotkin and Harrath, 2014). Previous study showed flavonoid compounds of ethanol extract of papaya peels were able to increase uterus weight and mammae gland proliferation (Novitasari, et al., 2018). Flavonoids such as isoflavone have a similar chemical structure to estrogen, so it can recover estrogen deficiency condition. The estrogenic action of mahogany seeds ethanolic extract (MSEE) on reproductive tissue and the underlying mechanism are not found yet. The present study was designed to determine the estrogenic activity of short term suplementation of MSEE to study the uterus development, bone density, and mammae gland proliferation of ovariectomized rats.

\section{MATERIALS AND METHODS}

\section{Plant and Extract Preparation}

The Swietenia mahogany (L.) Jacq seeds were collected from the Pancurbatu mahoni garden, North Sumatera, Indonesia. The seeds were shade dried for 7-10 days and then were finely powdered. The powder was extracted with ethanol for seven days. The extract was filtered through Whatman filter and concentrated by a rotary evaporator at $40^{\circ} \mathrm{C}$. The concentrated extract was dried under open air and stored in refrigeration.

\section{Animal Preparation}

The protocol of the study was approved by Animal Research Ethics Committee, Department of Biology, Faculty of Mathematic and Natural Sciences, Universitas Sumatera Utara with 0093/ KEPH-FMIPA/2019 reference number for notice of approval. Thirty female wistar rats, age 40-50 days were obtained from Animal House Universitas Sumatera Utara, Indonesia. The animal were grouped and housed in cages at temperature and humidity-controlled room and given access to food and water. The animals were adapted with laboratory condition for 10 days.

\section{Grouping of Animals}

Twenty five wistar female rats underwent bilateral ovariectomy by the dorsolateral approach anesthesized under ketamine (Ket-A-100®) $(80 \mathrm{mg} /$ $\mathrm{kg} \mathrm{BW})$ and xylazine (Xila ${ }^{\circledR}$, Interchemie) $(20 \mathrm{mg} /$ $\mathrm{kg} \mathrm{BW}$ ) intraperitoneally. The rats were allowed to recover for 14 days and then they were weighed and allocated to five ovariectomized (OVX) groups (group 2-6). Five other rats were grouped as control of non-ovariectomized rats (non-OVX) (Lusiana, 2017; Salahuddin, et al., 2019). Details regarding animal grouping as follow:

Group 1: non-OVX rats and received CMC-Na peroral (p.o.), daily.

Group 2: OVX rats received a suspension of 17- $\beta$ estradiol $(0.18 \mathrm{mg} / \mathrm{kg} \mathrm{BW})$ in CMC-Na (p.o., biweekly).

Group 3: OVX rats received given CMC-Na $0.5 \%$ BW p.o., daily.

Group 4: OVX rats received suspension of MSEE (50 mg/kg BW, p.o.)

Group 5: OVX rats received suspension of MSEE (100 mg/kg BW, p.o.).

Group 6: OVX rats received suspension of MSEE (200 mg/kg BW, p.o.).

\section{Vaginal Cornification}

On the $11^{\text {th }}$ day to the $14^{\text {th }}$ day, vaginal smears were taken every $4 \mathrm{~h}$ to observe the shape of epithelial cells in the estrus and diestrus phase and to know the length of time of the estrus cycle on estrus and diestrus phase. The vaginal smears were prepared by washing with $10 \mu \mathrm{L}$ of normal 
saline $(\mathrm{NaCl} 0.9 \%)$ and were then thinly spread on a glass slide. They were allowed to dry at room temperature and then stained using methylene blue. The slides were rinsed with distilled water after 30 min and allowed to dry. The smears were studied using the light microscope (10x40 magnification) and the cell type and their relative numbers were recorded. Vaginal smear cells were counted on 100 cells randomly (Jie, et al., 2015; Parhizkar, et al., 2011; Aswar, et al., 2014).

\section{Ratio of Uterus Weight to Body Weight}

On the last day of treatment, animals were weighed and sacrificed by cervical dislocation. The uteri were dissected out. The uterus ratios were then calculated by dividing the uterus weight in milligrams by body weights in grams. After the wet uteri were weighed, the wet uteri were dried in an oven with a temperature of $100^{\circ} \mathrm{C}$ for $24 \mathrm{~h}$, then weighed to obtain the dry weight of the uterine (Vijayanarayana, et al., 2007).

\section{Bone Density}

The femur, fibula and its tibia are cleared from the fat and soft tissue. Then the bones were dried for 2 weeks and their mass were measured using analytical scales while the dry bones volume was measured by a plethysmometer. After obtaining the mass and volume, then the bone density is calculated using the general density formula $\rho=\mathrm{m} / \mathrm{v}$ ( $\rho$ : density $\left(\mathrm{kg} / \mathrm{m}^{3}\right), \mathrm{m}$ : mass (gram), and v: volume $\left.\left(\mathrm{cm}^{3}\right)\right)$ (Nurrochmad, et al., 2010).

\section{Mammae Gland Histological Analysis}

Mammae glands were sliced then made in parrafin blocks and cut thinly with $4 \mu \mathrm{m}$ thick, then stained with haematoxylin eosin, mounted and covered with a glass deck. Qualitative observations were performed under a light microscope with 10x40 magnification, whereas quantitative test were used to calculate the number of lobulus cell using three different fields of view. The Ki-67 staining was done with the immunohistochemistry method to observe cell proliferation (Ramos-Vara, 2005; Blacher, et al., 2015).

\section{Data Analysis}

The data were expressed as mean $\pm \mathrm{SEM}$, or mean $\pm \mathrm{SD}$, and were calculated using one way ANOVA, continued with Tukey HSD Post Hoc test to see the differences between the treatments. Differences were considered statistically significant when $(p<0.05)$.

\section{RESULTS}

\section{Effect of MSEE on Vaginal Cornification}

The effect of MSEE on the shape of vaginal smear cells, the length of the estrus phase and the length of the diestrus phase were shown in Table 1 and Table 2. Based on the Mann-Whitney statistical test, it was found that group 1 did not show a significant difference $(p \geq 0.05)$ with group 2 (OVX + estradiol), group 5 (OVX + MSEE dose $100 \mathrm{mg} /$ $\mathrm{kg} \mathrm{BW}$ ), group 6 (OVX + MSEE dose $200 \mathrm{mg} / \mathrm{kg}$

Table 1. Average total time of the estrus phase.

\begin{tabular}{|c|c|c|c|c|}
\hline \multirow[t]{2}{*}{ Groups } & \multicolumn{4}{|c|}{ Hour (Mean \pm SEM) } \\
\hline & Day I & Day II & Day III & Day IV \\
\hline I. Non-OVX & $7.20 \pm 1.497$ & $8.00 \pm 1.789$ & $9.60 \pm 0.980$ & $9.60 \pm 1.600$ \\
\hline 2. OVX + estradiol & $6.40 \pm 2.040$ & $7.20 \pm 1.497$ & $8.80 \pm 1.497$ & $3.20 \pm 1.497$ \\
\hline 3. OVX + CMC-Na & $0.80 \pm 0.800$ & $1.60 \pm 0.980$ & $1.60 \pm 0.980$ & $1.92 \pm 2.191$ \\
\hline 4. OVX + MSEE $50 \mathrm{mg} / \mathrm{kg} \mathrm{BW}$ & $1.00 \pm 0.980$ & $3.20 \pm 1.497$ & $4.80 \pm 1.497$ & $5.60 \pm 2.400$ \\
\hline 5. OVX + MSEE $100 \mathrm{mg} / \mathrm{kg} \mathrm{BW}$ & $3.20 \pm 1.497$ & $4.00 \pm 1.789$ & $7.20 \pm 1.497$ & $6.40 \pm 0.980$ \\
\hline 6. OVX + MSEE $200 \mathrm{mg} / \mathrm{kg} \mathrm{BW}$ & $1.80 \pm 1.197$ & $5.60 \pm 2.400$ & $6.40 \pm 2.713$ & $7.20 \pm 2.332$ \\
\hline
\end{tabular}


Table 2. Average total time of the diestrus phase.

\begin{tabular}{lcc}
\hline Group & $\begin{array}{c}\text { Weight Ratio of Wet } \\
\text { Uterus } \pm \text { SEM }\end{array}$ & $\begin{array}{c}\text { Weight Ratio of Dry } \\
\text { Uterus } \pm \text { SEM }\end{array}$ \\
\hline I. Non-OVX & $0.31 \pm 0.021$ & $0.070 \pm 0.004$ \\
2. OVX + estradiol & $0.29 \pm 0.018$ & $0.068 \pm 0.003$ \\
3. OVX + CMC-Na & $0.15 \pm 0.008$ & $0.034 \pm 0.005$ \\
4. OVX + MSEE $\mathbf{5 0 ~} \mathbf{~ m g / k g ~ B W ~}$ & $0.17 \pm 0.010$ & $0.037 \pm 0.003$ \\
$\mathbf{5 . ~ O V X + ~ M S E E ~ 1 0 0 ~} \mathbf{~ m g / k g ~ B W ~}$ & $0.25 \pm 0.024$ & $0.058 \pm 0.003$ \\
6. OVX + MSEE $\mathbf{2 0 0} \mathbf{~ m g / k g ~ B W ~}$ & $0.28 \pm 0.010$ & $0.062 \pm 0.003$ \\
\hline
\end{tabular}

BW) but significantly different with group 3 (OVX+ CMC-Na) and group 4 (OVX + MSEE group 50 $\mathrm{mg} / \mathrm{kg} \mathrm{BW}$ ). The condition of ovariectomized rats in group 3 is analog to postmenopausal condition which characterized by low estrogen levels leading to sexual disfunction, vaginal atrophy and osteoporosis (Liu, et al., 2018).

Table 1 showed that the estrus cycle average total time of the estrus phase for four days in group 3 (OVX + CMC-Na) was shorter compared to others. This proved that ovariectomized rats given estradiol and MSEE can still return to the estrus phase better than the CMC-Na group.

Based on Table 2, the diestrus phase for four days showed that all treatment groups gave a significant difference when compared with the CMC-Na group which had a longer time in the diestrus phase. This shows that the administration of MSEE and estradiol caused an extension of the diestrus phase in ovariectomized rats, and reduced the length of time diestrus in ovariectomized rats. The results of observing the estrus cycle in rats that were carried out for 1 cycle (4 days) with different treatments produced relatively different cycles. Differences on the daily estrus cycle including each group are influenced by the condition of the estrus cycle that is not simultaneously every rat.
Observation of vaginal smear in all groups has other phases besides the estrus and diestrus phases, namely the proestrus phase and the matestrus phase. The representative observation of the estrus cycle length in the vaginal smear of female mice in 4 phases (Proestrus - Estrus - Matestrus - Diestrus) could be seen in Figure 1.

\section{Effect of MSEE on Uterus Weight to Body Weight Ratio}

The effect of MSEE on the weight of wet and dry uteri weight were shown in Table 3 and Figure 2. Based on the Post Hoc Tukey HSD, the results showed that group 3 (OVX + CMC-Na)

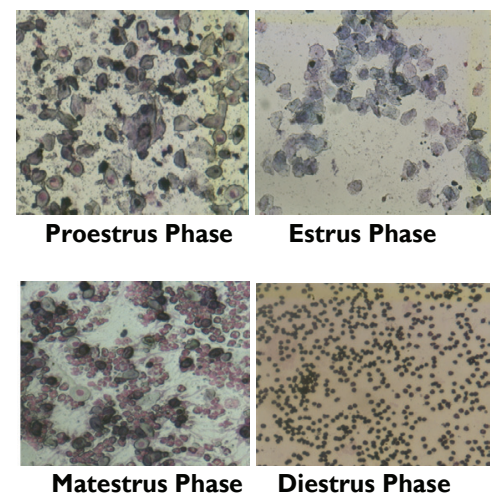

Figure 1. The representative figures of estrus cycle in 4 phases.

Table 3. Weight ratio of wet and dry uterus.

\begin{tabular}{lcc}
\hline \multicolumn{1}{c}{ Group } & $\begin{array}{c}\text { Weight Ratio of Wet } \\
\text { Uterus } \pm \text { SEM }\end{array}$ & $\begin{array}{c}\text { Weight Ratio of Dry } \\
\text { Uterus } \pm \text { SEM }\end{array}$ \\
\hline I. Non-OVX & $0.31 \pm 0.021$ & $0.070 \pm 0.004$ \\
2. OVX + estradiol & $0.29 \pm 0.018$ & $0.068 \pm 0.003$ \\
3. OVX + CMC-Na & $0.15 \pm 0.008$ & $0.034 \pm 0.005$ \\
4. OVX + MSEE $\mathbf{5 0 ~} \mathbf{~ m g / k g ~ B W ~}$ & $0.17 \pm 0.010$ & $0.037 \pm 0.003$ \\
5. OVX + MSEE 100 $\mathbf{~ m g / k g ~ B W ~}$ & $0.25 \pm 0.024$ & $0.058 \pm 0.003$ \\
6. OVX + MSEE 200 $\mathbf{~ m g / k g ~ B W ~}$ & $0.28 \pm 0.010$ & $0.062 \pm 0.003$ \\
\hline
\end{tabular}


Hasibuan, et al., 2020

Indones. J. Cancer Chemoprevent., 11(2), 75-83

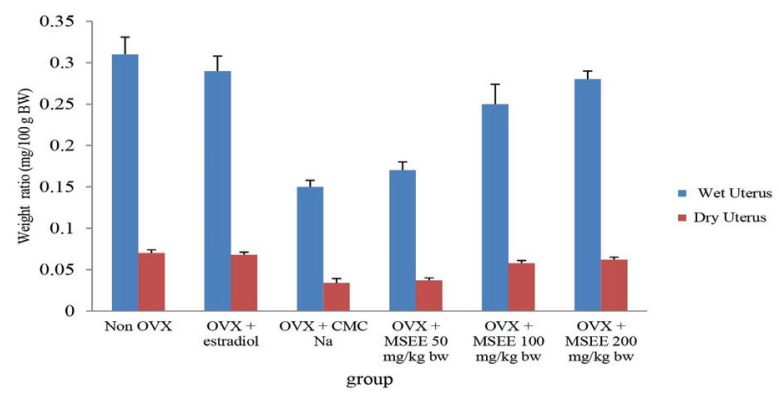

Figure 2. The average weight ratio of uterus.

did not have a significant difference $(p \leq 0.05)$ with group 4 (MSEE group dose of $50 \mathrm{mg} / \mathrm{kg} \mathrm{BW}$ ) but had a difference with group 1 (non-OVX non ovariectomized group), group 2 (17- $\beta$ estradiol 0.18 $\mathrm{mg} / \mathrm{kg} \mathrm{BW}$ ), group 5 (MSEE dose $100 \mathrm{mg} / \mathrm{kb} \mathrm{BW}$ ), and group 6 (MSEE dose $200 \mathrm{mg} / \mathrm{kg} \mathrm{BW}$ ). This showed that the MSEE 100 and $200 \mathrm{mg} / \mathrm{kg}$ BW were able to increase the weight of the uterus better than the MSEE $50 \mathrm{mg} / \mathrm{kg} \mathrm{BW}$. Based on the description above it can be concluded that MSEE doses of 100 and $200 \mathrm{mg} / \mathrm{kg} \mathrm{BW}$ were able to increase the uterus weight of female rats that had been ovariectomized. This phenomenon suggested that low dose of MSEE was not enough to give a significant effect

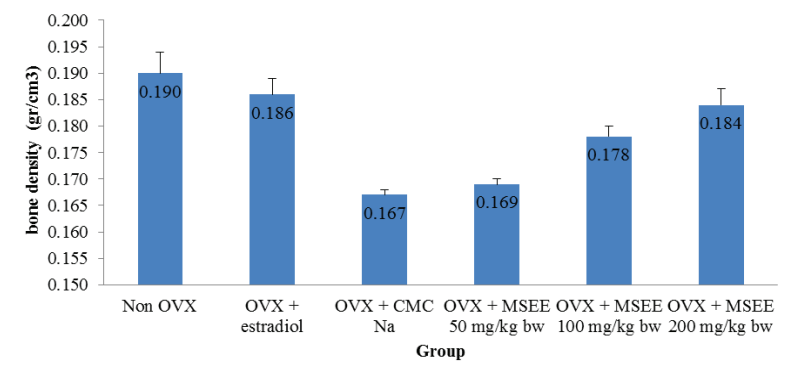

Figure 3. Average bone density.

to uterus development. In Figure 2 it could be seen that group 3 (given $\mathrm{CMC}-\mathrm{Na}$ 0.5\% BW) showed the lowest weight.

\section{Effect of MSEE on Bone Density Analysis}

This result showed that group 3 (OVX + CMC-Na) was not significant ( $p>0.005$ ) to group 4 (OVX + MSEE $50 \mathrm{mg} / \mathrm{kg} \mathrm{BW}$ ) and group 5 (OVX

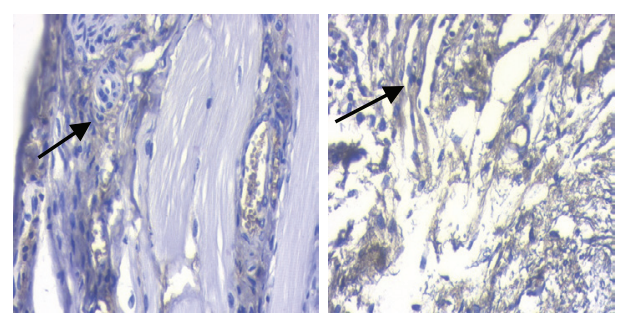

non OVX

(OVX + estradiol)

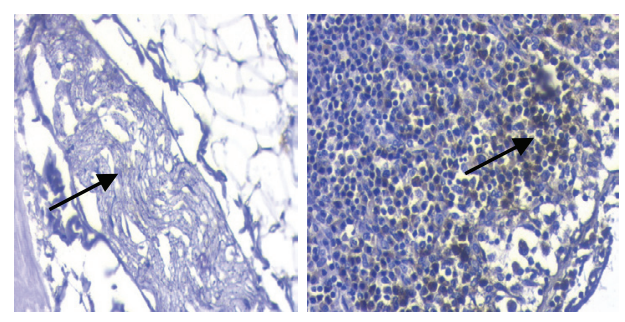

$(\mathrm{OVX}+\mathrm{CMCNa})$

(OVX + MSEE $50 \mathrm{mg} / \mathrm{kg} \mathrm{BW)}$
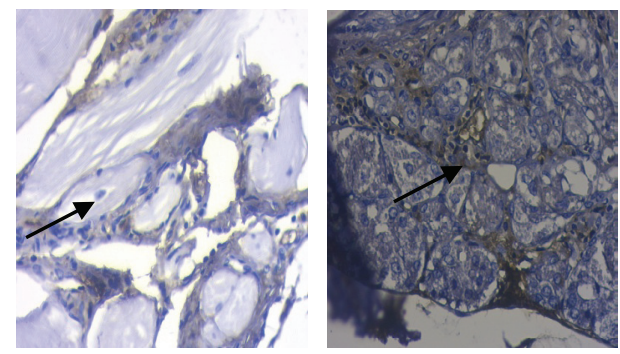

$(O V X+$ MSEE $100 \mathrm{mg} / \mathrm{kg} \mathrm{BW}) \quad(\mathrm{OVX}+$ MSEE $200 \mathrm{mg} / \mathrm{kg}$ BW)

Figure 4. Ki-67 staining of epithelial cell of rats mammary glands. 
Table 4. Ki-67 expression score on epithelial cells of mammary breast gland.

\begin{tabular}{|c|c|}
\hline Group & Mean Score Expression (\%₫SD) \\
\hline I. Non-OVX & $80.7 I \pm 4.67 \mathrm{ab}$ \\
\hline 2. OVX + estradiol & $40.21 \pm 2.40^{b}$ \\
\hline 3. $\mathrm{OVX}+\mathrm{CMC}-\mathrm{Na}$ & $5.35 \pm 2.99 a$ \\
\hline 4. OVX + MSEE $50 \mathrm{mg} / \mathrm{kg}$ BW & $54.80 \pm 12.1 I^{a}$ \\
\hline 5. OVX + MSEE $100 \mathrm{mg} / \mathrm{kg} \mathrm{BW}$ & $67.52 \pm 3.95^{\mathrm{ab}}$ \\
\hline 6. OVX + MSEE $200 \mathrm{mg} / \mathrm{kg} \mathrm{BW}$ & $76.18 \pm 2.18 \mathrm{ab}$ \\
\hline
\end{tabular}

\section{Information:}

a. Sig $(p)<0.05=$ significantly difference with group 2

b. Sig $(p)<0.05=$ significantly differences with group I

+ MSEE $100 \mathrm{mg} / \mathrm{kg} \mathrm{BW}$ ). Group 5 was not significant to group 6 (OVX + MSEE $200 \mathrm{mg} / \mathrm{kg} \mathrm{BW})$. Whereas group 6 was significant to group 3 (OVX + CMC-Na) but was not significant to group 1 (non -OVX) and group 2 (OVX + estradiol). The data showed that the MSEE $200 \mathrm{mg} / \mathrm{kg}$ BW was able to increase the bone density of ovariectomized rats better than the MSEE dose of 50 and $100 \mathrm{mg} / \mathrm{kg}$ BW. Based on figure 3, the mean bone density in group 3 (OVX + CMC-Na) was the lowest. This might be caused by hypoestrogenic condition so that the osteoclast process was uncontrolled and resulted in a decrease on bone density (Aswar, 2017). In group 2 (OVX + estradiol) and group 4, 5 and 6 (OVX + MSEE), the average bone density was greater than group $3(\mathrm{OVX}+\mathrm{CMC}-\mathrm{Na})$ due to estradiol and MSEE replaced estrogen as hormone therapy.

\section{Effect of MSEE on Mammae Gland Pro- liferation}

Non ovariectomized and ovariectomized rats have differences in the development of breast epithelial cells. Figure 4 showed that MSEE was able to stimulate the development of rat mammary gland epithelial cells. Qualitatively, it was observed that the number of ephitelial cells of mammary glands of ovariectomized rats in group 3 (OVX + $\mathrm{CMC}-\mathrm{Na}$ ) was the fewest than the other groups, representing menopausal condition.

\section{Scores of Ki-67 Expression on Mammae Gland Epithelial Cells}

The number of proliferative cells were measured using Ki67 immunolabelling to validate the estrogenic effect of MSEE on mammary gland development. Scores of Ki-67 expression of epithelial cell of rats mammary glands could be seen in Table 4. Calculation of Ki-67 expression scores in 200 cells per treatment groups was done using a light microscope with magnification of 40x.

In this study, the expression of Ki-67 epithelial cells of mammary gland were aimed to see the estrogenic effect of MSEE on mammary gland development. The increasing of epithelial cell proliferation might be caused by increasing level of estrogenic activity on ovariectomized rats. The mammary gland development in group 4, 5 and 6 (OVX + MSEE) were significantly different from group 3 (OVX + CMC-Na). From these results, MSEE showed to increase the development of mammae gland by increasing the breast cell proliferation.

\section{DISCUSSION}

This study aimed to determine the effect of MSEE on the development of the uterine, bone density, and the mammae gland proliferation on ovariectomized rats. The administration of MSEE had an effect on the estrus phase of rats. It was assumed 
that the isoflavone compounds found in MSEE have estrogen-like effects. According to (Jie, et al., 2015), the uterus weight was directly proportional to the length of time in the estrus phase cycle. The higher the uterus weight the longer the estrus phase. The lowest weight of ovariectomized rats on group 3 can be caused by the ovariectomy done in rats that caused the absence of the ovary as the main source of estrogen. Estrogen plays role for the proliferation of uterine cells. The absence of estrogen secretion resulting in atrophy in the uterus and causing the uterus to not develop (Keiler, et al., 2015). Estrogen stimulates the increase of water content in cell, DNA, RNA and protein synthesis, and activation of enzymes in the uterus (Sirotkin and Harrath, 2014). Whereas the ovariectomized rats given MSEE showed a significant increase in uterus weight. In the uterus, the bond between estrogen and the ER- $\alpha$ receptor causes proliferation of uterine cells, luminal ephitelium and uterine estrogen receptor genes that impact on increased uterus weight (Keiler, et al., 2015; Aswar, et al., 2014).

The deficiency of estrogen results in over differentiation of osteoclast cells, so that resorptioning the bone excessively. The excessive bone resorption will decrease the bone density and be one cause of osteoporosis (Murkies, et al., 1998; Lestari, et al., 2018; Triutomo, et al., 2017). Decrease of estrogen production will be followed by increase calcium lost from the body (Dianingati, et al., 2015). These results are suspected to be related to the compound contained in MSEE, namely flavonoid wich is an antioxidant. According Prasetiawan, et al., (2017), the MSEE have antioxidant and work sinergistically with $\mathrm{Cu}$ and $\mathrm{Zn}$-SOD in increasing antioxidant status in the body. The isoflavones have many effects in humans such as inhibiting osteoclast, increasing follicular phase length, reducing the total cholesterol and protecting againts the development of breast and prostate cancers (Murkies, et al., 1998).
Estrogenic compounds in MSEE might reduce the increase of osteoclasts. Liu, et al., 2018, have studied that water extract of Epimedium restored both femura and humerus after 16 weeks treatment, increased both serum BGP (ß-carboxyglutamic acid-containing protein) and $\mathrm{OPG}$ (osteoprotegerin) level. The BPG, a bone formation indicator, and OPG, a bone resorption indicator, are indicators which show the effect of an extract treatment on bone turnover. This study indicated that flavonoid increased the bone strength of ovariectomized rats. The mechanism might be mediated by inhibition of osteoclast activity through OPG, which is a decoy reseptor in the activator of osteoclasts (Dianingati, et al., 2015). Phytoestrogen suppress the rate of bone resorption and enhance the bone formation rate (Nurrochmad, et al., 2010; Sirotkin and Harrath, 2014).

The decrease number of mammary gland epithelial cells on ovariectomized rats is similar with the menopause women condition. The epithelial cells of mammary gland on menopausal condition become shrinkage and involution.

The glandular epithelium becomes atrophy and only a few remnants of the ductal system remain. Cystic widening often occurs from the rest of this duct. Connective tissue also becomes more dense and homogeneous (Agustini, et al., 2005; Gerard, et al., 2019). Murkies, et al. (1998) have proved that genistein as the phytoestrogen has been shown to exert both proliferative (estrogenic) and antiproliferative (antiestrogenic) effect in human cell lines. The stimulation of cell growth occuring at low concentration and the inhibition at the higher concentration.

\section{CONCLUSION}

Based on this study, it can be concluded that MSEE dose $100 \mathrm{mg} / \mathrm{kg} \mathrm{BW}$ and $200 \mathrm{mg} / \mathrm{kg}$ $\mathrm{BW}$ increase uterus weight and length of the es- 
trous phase of ovariectomized rats. MSEE dose of $200 \mathrm{mg} / \mathrm{kg}$ BW increase bone density of ovariectomized rats. MSEE has increase mammary gland development in ovariectomized mice breast glands.

\section{ACKNOWLEDGEMENT}

The authors are grateful thank to Faculty of Pharmacy, Universitas Sumatera Utara for the facilities support.

\section{REFERENCES}

Agustini, K., Wiryowidagdo, S. and Kusmana, D., 2005, Pengaruh Pemberian Ekstrak Biji Klebet (Trigonella foenum-graecum L.) Terhadap Kadar Hormon Estradiol Dan FSH Plasma Tikus Putih Betina Galur Wistar Prepubertal, Majalah Ilmu Kefarmasian, 2(2), 74-83.

Anderson, E., Clarke, R.B. and Howeli, A., 1998, Estrogen Responsiveness and Control of Normal Human Breast Proliferation, Journal of mammary Gland Biology and Neoplasia, 3(1), 23-35.

Aswar, U., Gurav, M., More, G., Rashed, K. and Aswar, M., 2014, Effect of aqueous extract of Solanum xanthocarpum schard. \& Wend. on postmenopausal syndrome in ovariectomized rats, Journal of integrative medicine, 12(5), 439-446.

Chlebowski, R.T., Kuller, L.H., Prentice, R.L., Stefanick, M.L., Manson, J.E., Gass, M., et al., 2009, Breast Cancer after Use of Estrogen plus Progestin in Postmenopausal Women, N. ENGl. J. Med., 360(6), 573-587.

Dianingati, R.S., Novarina, A., Hana, A.K., Muntafi'ah, L. and Lukitaningsih, E., 2015, The combination of High Calcium Milk With Citrus Maxima Peels Ethanolic Extract Increased Bone Density of Ovariectomized Rats, Indonesia J. Cancer Chemoprevent, 6(2), 42-48.

Gerard, C., Blacher, S., Communal, L., Courtin, A., Tskitishvili, E., Mestdagt, M., et al., 2015, Estetrol is a week estrogen antagonizing estradiol-dependent mammary gland proliferation, Journal of Endocrinology, 224(1), 85-95.
Jie, D., Ying, X., Xiaoping, M., Jinna, A., Xiudong, Y., Zhiqiang, L., et al., 2015, Estrogenic effect of the extract of Ranshen (Radix ginseing) on reproductive tisssue in immature mice, Journal of traditional Chinese Medicine, 35(4), 460-467.

Keiler, A.M., Dorfelt, P., Chatterjee, N., Helle, J., Bader, M.I., Vollmer, G., et al., 2015. Assessment of the effects of naringenin-type flavones in uterus and vagina, Journal of steroid Biochemistry and molecular biology, 145(1), 4957.

Keiler, A.M., Macejova, D., Dietz, M.B., Bolton, J.L., Pauli, G.F., Chen, S.N., et al., 2017, Evaluation of estrogenic potency of standardized hops extract on mammary gland biology on MNU- induced mammary tumor growth in rats, Journal of steroid Biochemistry and molecular biology, 174(1), 234-241.

Lestari, B., Walidah, Z., Utomo, R.Y., Murwati, R. and Meiyanto, E., 2019, Suplementation with extract of pumpkin seeds exerts estrogenic effects upon the uterin, serum lipids, mammary glands, and bone density in ovariectomized rats, Phytotherapy research, 2019, 1-10.

Liu, H., Xiong, Y., Wang, H., Yang, L., Wang, C., Liu, X., et al., 2018, Effects of Water extract from epimedium on neuropeptide signaling in an ovariectomized osteoporosis rat model, Journal of Ethnopharmacology, 221(1), 126-136.

Lusiana, N., 2017, Pengaruh Fitoestrogen Daging Buah Kurma Ruthab (Phoenix dactylifera L.) terhadap sinkronisasi siklus estrus mencit (Mus musculus L., ) betina, Klorofil, 1(1), 24-31.

Mendelsohn, M.E. and Karas, R.H., 2010, Rapid Progess for Non-nuclear Estrogen Receptor Signaling, J. Clin. Invest., 120(7), 2277-2279.

Murkies, A.L., Wilcox, G. and Davis, S.R., 1998, Phytoestrogen, Journal of Clinical Endocrinology and Metabolism, 83(2), 297-303.

Nurrochmad, A., Leviana, F., Wulancarsari, C.G. and Lukitaningsih, E., 2010, Phytoestrogen of osteoporosis, International Journal of Phytomedicine, (2), 363-372.

Novitasari, D., Devyanto, H.T., Arifah, F.H., 
Ivanawati, A., Ulum, Z. and Murwanti, R., 2018, Estrogenic Activity of Ethanolic Extract of Papaya Peels (Carica Papaya L.) on Uterine Weight And Mammae Gland Proliferation on Ovariectomy Rats, Indonesia J. Cancer Chemoprevent, 9(2), 86-91.

Parhizkar, S., Latiff, L.A., Rahman, S.A., Dollah, M.A. and Parichehr, H., 2011, Assesing Mahogany (Swietenia Mahogani L. Jacq) Seeds In The Liver Tissue of Diabetic Experimental Rats Estrogenic Activity of Nigella sativa in Ovariectomized Rats Using Vaginal Cornification Assay, African Journal of Pharmacy and Pharmacology, 5(2), 137142.

Prasetiawan, E., Adnyane, K.M. and Wresdiyati, T., 2017, The Antioxidant Activieties of Ethanol Extract of Swietenia mahogany L., Jurnal Kedokteran Hewan, 11(2), 57-61.

Ramos-Vara, J.A., 2005, Technical Aspects of Immunohistochemistry, Vet Pathol, 42, 405-426.
Salahuddin, M.S., Safitri, E., Yunita, M.N., Susilowati, S., Hamid, I.S. and Yudhana A., 2019, Pengaruh Ekstrak Kedelai (Glycine max) Terhadap Proliferasi Lapisan Endometrium Mencit (Mus musculus), Jurnal Medik Veteriner, 2(1), 49-54.

Sirotkin, A.V. and Harrath, A.H., 2014, Phytoestrogens and Their Effects, European Journal of Pharmacology, 741, 230-236.

Triutomo, D.H., Miranda, A., Tamba, L.J. and Lukitaningsih, E., 2017, Estrogenic Effect Ethanol Extract Corn Silk (Stigma maydis) on Bone Density and Histology Femur Profiles in Ovariectomized Rats Female Sprague Dawley Strain, Indonesia J. Cancer Chemoprevent, 7(3), 104-109.

Vijayanarayana, K., Rodrigues, R.S., Chandrashekhar K.S., and Subrahmanyam E.V., 2007, Evaluation of Estrogenic activity of Alcoholic extracts of rhizhomes of curculigoorchioides, J Ethnopharmacol, 114(2), 241-245. 